\title{
Sexual Initiation, Substance Use, and Sexual Behavior And Knowledge Among Vocational Students In Northern Thailand
}

ByAlice Liu, Peter Kilmarx,

Richard A. Jenkins,

Chomnad

Manopaiboon,

Philip A. Mock,

Supaporn

Jeeyapunt, Wat

Uthaivoravit and

Frits van Griensven

Alice Liu is a resident, Stanford University School of Medicine, Stanford, CA, USA.

Peter Kilmarx is chief of epidemiology,

Division of HIV/AIDS

Prevention, Centers

for Disease Control and Prevention

(CDC), Atlanta, GA,

USA. Richard A.

Jenkins worked on this article while a senior

behavioral scientist,

Division of HIV/AIDS

Prevention, CDC.

Chomnad Manopai-

boon is chief of special populations, Philip A.

Mock is chief of infor-

matics and data management, Supaporn Jeeyapunt is a data analyst and Frits van

Griensven is chief of

behavioral research-

all at the Thailand

Ministry of Public

Health-U.S. CDC

Collaboration, Non-

thaburi, Thailand.

Wat Uthaivoravit

is director of social

preventive medicine,

Chiang Rai Regional

Hospital, Chiang Rai,

Thailand.

CONTEXT: Thailand has undergone dramatic social changes in the last two decades, yet little is known about factors related to sexual initiation among adolescents.

METHODS: A survey using the audio computer-assisted self-interviewing method was conducted to assess social and demographic characteristics, substance use, sexual behavior, and knowledge of HIV and STIs among 1,725 vocational school students aged 15-21 living in northern Thailand. Gender differences for these factors were evaluated using chisquare and Mann-Whitney U tests. Multivariate survival analysis using Cox proportional hazards models assessed associations between these variables and sexual initiation for each gender.

RESULTS: Males initiated sexual intercourse at an earlier age than females (median ages of 17 and 18, respectively). At any given age, sexual initiation was associated with having a nonagricultural background and using alcohol or methamphetamine (adjusted rate ratios, 1.3-2.9). For males, initiation was also associated with having parents who did not live together, having a friend as a confidant, tobacco use, high perceived risk for HIV and high STI knowledge (1.3-1.7). For females, other factors associated with earlier initiation were younger age at interview, living away from family, lacking a family member as a confidant, high perceived risk for STIs and ever having smoked marijuana (1.3-2.4).

CONCLUSIONS: Interventions to ameliorate the adverse consequences of early sexual initiation need to address social influences such as parents and peer groups. Programs should identify and target high-risk subgroups, such as those who are sexually experienced at an early age and those engaged in patterns of generalized risk-taking. International Family Planning Perspectives, 2006, 32(3):126-135

Among unmarried young people in Thailand, sexual behavior norms have changed substantially over the last two decades. One important change has been the increased acceptability of premarital sex among young women, which has resulted in a trend toward earlier sexual initiation for Thai females. A nationwide partner relations survey conducted in 1990 found that 13\% of female participants aged 15-19 reported having had sexual intercourse, compared with $34 \%$ of males. ${ }^{1}$ Other studies from the same period found that young Thai women had higher levels of experience, though they were still less likely to be sexually experienced than their male counterparts. ${ }^{2}$

Thai cultural norms generally have granted sexual freedom to males, but imposed constraints on female sexual behavior. In the past, unmarried males often experienced sexual initiation with female sex workers, and young unmarried females were expected to maintain premarital chastity.

Studies over the last decade have suggested that the norms governing sexual practices among Thai adolescents and young adults have changed. ${ }^{3}$ A growing proportion of adolescent females report having had sexual intercourse, while male patronage of sex workers has decreased substantially. Most Thai men now have their early sexual experience with noncommercial partners. ${ }^{4}$ Males' age at sexual initiation in Thailand does not appear to have changed in recent decades; however, as social controls have eased, young women appear to be having sex earlier. Yet a key difference remains: Young unmarried males usually have more partners, particularly more casual partners, than their female counterparts. ${ }^{5}$

These shifts in sexual behavior have potentially adverse consequences for Thai youth, particularly for young women. In other countries, sexually active young people have an increased risk of HIV infection and other STIs, as well as elevated rates of unplanned teenage pregnancy and pregnancy termination. ${ }^{6}$ Understanding the factors associated with initiation of sexual intercourse is crucial in trying to design and deliver interventions for Thai youth (particularly females) who are likely to have sex at ages earlier than the norm.

Two studies have reanalyzed data from a national survey of 15-24-year-old Thais conducted in the mid-1990s ${ }^{7}$; they focused on the association of age at sexual initiation with risk-taking behaviors, social and psychological factors, variables related to family and friends, and social and demographic characteristics. One analysis looked at the entire age range of survey participants, and the other considered only 15-19-year-olds. Several qualitative studies have also explored this subject. ${ }^{8}$ Growing up without both parents and having sexually experienced friends were found to be associated with premarital sexual initiation. ${ }^{9}$ For fe- 
males, urban residence ${ }^{10}$ and going to nightclubs ${ }^{11}$ were associated with a greater likelihood of having premarital sex; for males, poor family relationships, ${ }^{12}$ living apart from family ${ }^{13}$ or living with parents, ${ }^{14}$ and high levels of alcohol consumption ${ }^{15}$ were related to a greater likelihood of premarital sexual activity.

Research in other countries has used various models to explore which factors are related to age at sexual initiationfor example, biological and behavioral correlates such as pubertal development and leisure activities, as well as social factors such as the influences of family, peers and institutions (education and religion). ${ }^{16}$ Other studies have looked at substance use and mental health problems, but these have generally lacked an overarching conceptual framework.

In this study, we assessed factors associated with age at sexual initiation among adolescents from Chiang Rai, Thailand's northernmost province. It borders Laos and Myanmar in the Golden Triangle region, which is known for drug production and trafficking. Most of the 1.3 million people of Chiang Rai province are northern Thai and live in rural, agricultural lowlands; $13 \%$ are ethnic highland minorities ("hill tribes"). ${ }^{17}$ The province's HIV prevalence was among the highest in the country during the early years of the Thai epidemic; ${ }^{18}$ prevalence peaked among female sex workers in 1991 (62\%), with subsequent peaks among 21-year-old male military conscripts (17\% in 1993) and primigravid women (11\% in 1994). Deaths among men and women aged 20-29 increased 9-10-fold in subsequent years. From analyses of the age distribution of AIDS cases and AIDSrelated deaths, most HIV infection likely occurred during adolescence and young adulthood. ${ }^{19}$

Our sample comprised students recruited from vocational schools that provided upper secondary and postsecondary education in a variety of manual trades and occupations. The lone previous study of Thai vocational students found lower levels of HIV risk behavior among students in Bangkok than among factory workers and such traditional risk groups as clients of STI clinics. ${ }^{20}$ Upper secondary and postsecondary education of all kinds is increasingly common in Thailand ${ }^{21}$ and serves as an avenue for social mobility, especially for rural and urban youth in provincial areas. The schools that we sampled were located in rural and urban areas and, as vocational institutions, did not draw from the most economically advantaged strata of Thai society. Therefore, we believed they were an appropriate sample for examining sexual and drug use risks in a population exposed to recent social change.

The literature provides a limited theoretical framework for assessing the factors related to sexual initiation. We believed it was important to consider the range of social and behavioral factors that have been treated in past studies, including modifiable factors such as drug and alcohol use, recent sexual behavior, peer norms, relationships with parents, and knowledge of HIV and STIs, as well as factors that are less amenable to intervention, such as age, family structure, urban or rural residence, and family background. We
TABLE 1. Characteristics of vocational school students aged 15-21, according to gender, Chiang Rai, Thailand, 1999

\begin{tabular}{|c|c|c|}
\hline Characteristic & $\begin{array}{l}\text { Male } \\
(\mathrm{N}=893)\end{array}$ & $\begin{array}{l}\text { Female } \\
(\mathrm{N}=832)\end{array}$ \\
\hline \multicolumn{3}{|l|}{ Demographic } \\
\hline Gender (\%) & 51.8 & 48.2 \\
\hline Mean (median) age & $18.5(18)$ & $18.4(18)$ \\
\hline \multicolumn{3}{|l|}{ Age } \\
\hline $15-17(\%)$ & 29.1 & 27.8 \\
\hline $18-19(\%)$ & 43.4 & 45.1 \\
\hline $20-21(\%)$ & 27.4 & 27.2 \\
\hline Northern Thai (\%) & 92.7 & 94.8 \\
\hline Parent works in agriculture (\%) & 69.3 & 68.9 \\
\hline Parents live together (\%)† & 81.0 & 77.0 \\
\hline Lives with parents (\%) & 61.8 & 57.1 \\
\hline \multicolumn{3}{|l|}{ Substance use } \\
\hline Ever went out dancing or drinking (\%) & 92.0 & $83.3^{* * *}$ \\
\hline Drank any alcohol in past 3 mos. (\%) & 92.5 & $80.5^{* * *}$ \\
\hline Ever drove motorcycle after having $\geq 3$ drinks (\%) & 77.5 & $52.5^{* * *}$ \\
\hline Smoked cigarettes in past 3 mos. (\%) & 52.4 & $14.5^{* * *}$ \\
\hline Ever used methamphetamine (\%) & 39.2 & $18.0^{* * *}$ \\
\hline Ever used marijuana (\%) & 21.5 & $3.6^{* * *}$ \\
\hline \multicolumn{3}{|l|}{ Sexual behavior } \\
\hline Had no sexual contact or intercourse (\%)‡ & 33.8 & $41.6^{* *}$ \\
\hline Had sexual contact only (\%) & 17.9 & 15.3 \\
\hline Mean (median) age at first contact & $16.0(16)$ & $17.2(17)^{* * *}$ \\
\hline Had sexual intercourse (\%) & 48.3 & 43.1 \\
\hline Mean (median) age at first intercourse & $16.7(17)$ & $17.7(18)^{* * *}$ \\
\hline Used condom at first intercourse (\%) & 23.2 & 25.6 \\
\hline Had steady sexual partner(s) in past 3 mos. (\%)§ & 41.8 & $46.6^{*}$ \\
\hline Had casual sexual partner(s) in past 3 mos. (\%) & 16.2 & $4.8^{* * *}$ \\
\hline Mean (median) lifetime number of sexual partners & $4.6(2)$ & $2.8(1)^{* * *}$ \\
\hline Ever bought sex (\%) & 6.5 & $0.5^{* * *}$ \\
\hline Ever sold sex (\%) & 2.7 & 3.1 \\
\hline Ever been coerced to have sex (\%)†† & 6.5 & $21.0^{* * *}$ \\
\hline Homosexual or bisexual (\%) & 9.1 & 11.2 \\
\hline
\end{tabular}

${ }^{*} \mathrm{p}<.05 .{ }^{* *} \mathrm{p}<.01 .{ }^{* * *} \mathrm{p}<.001$. † Marriages are commonly not legally registered in Thailand, particularly in rural areas, hence "parents live together" includes both registered and unregistered marriages. ¥Sexual contact was defined as the respondent touching someone else's genitals, or someone else touching the respondent's genitals, for the purpose of erotic stimulation; this included oral sex, but not vaginal or anal penetration. §A steady sexual partner was someone the respondent had known for at least two months, had sexual contact or intercourse with regularly, and felt an emotional bond with; a casual partner was someone whom the respondent had sexual contact or intercourse with and who was not a steady partner, and with whom no money was ex-

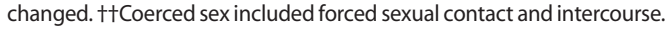

also included variables that have emerged as important correlates of risk behavior in Thailand, such as sexual coercion $^{22}$ and sexual orientation. ${ }^{23}$ This study's primary objective was to identify factors that should be incorporated into interventions aimed at improving the sexual health of Thai adolescents and young adults.

\section{METHODS}

\section{Sample}

In November and December 1999, we invited 1,736 students aged 15-21 who attended three vocational schools in Chiang Rai to participate in a cross-sectional survey of sexual and drug use behavior. After providing written informed consent (persons 15 or older do not need parental consent in Thailand), ${ }^{24} 1,725$ students completed computer-administered questionnaires in a classroom equipped as a computer laboratory, using monitors with hoods to maximize privacy. Equal enrollment quotas were set for males and females, as well as for each of the six grade levels in the schools. The study protocol was approved by the ethical review committee of the Thai Ministry of Public 


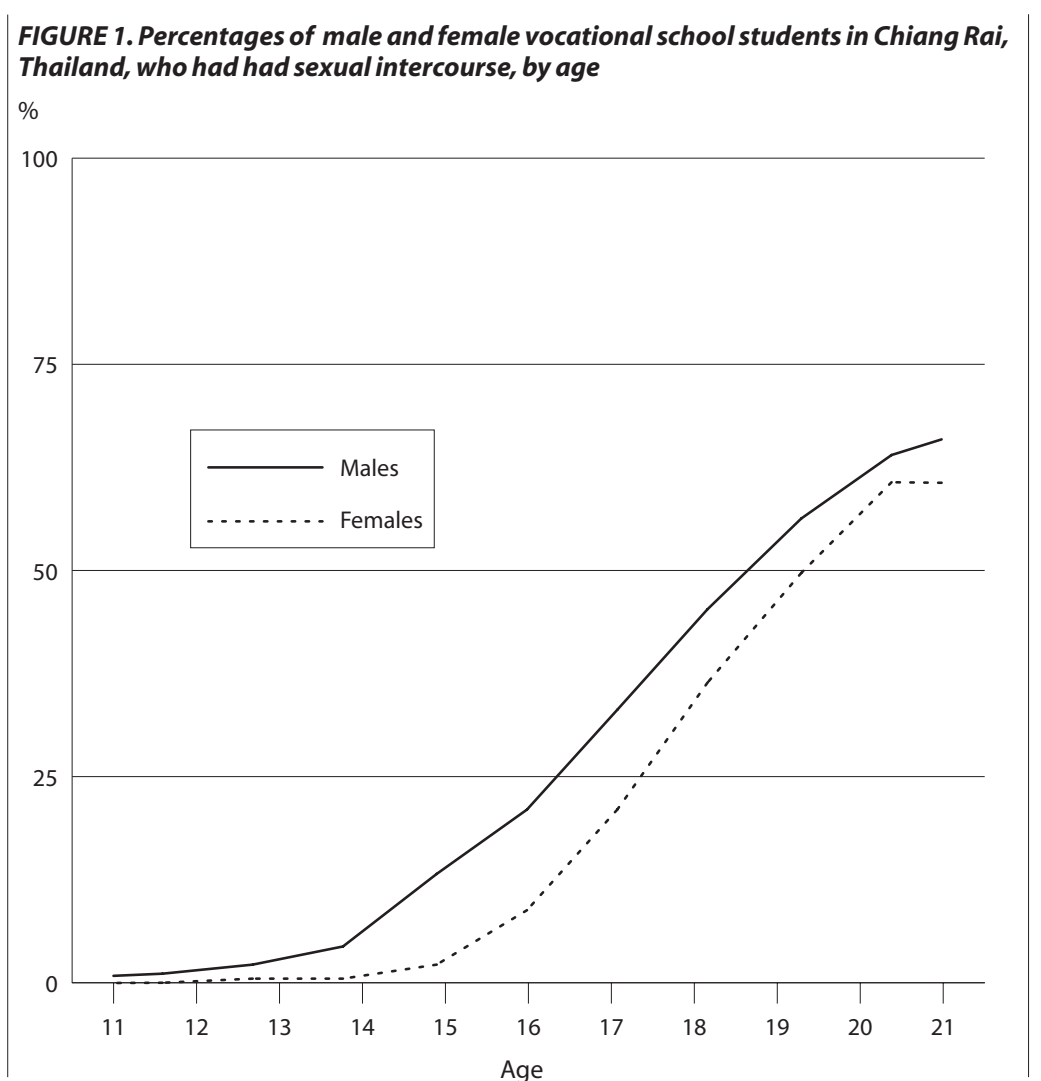

Health and by the institutional review board of the U.S. Centers for Disease Control and Prevention. A detailed description of the study procedures has been reported elsewhere. $^{25}$

\section{Measurement}

The study's questionnaire was administered using the audio computer-assisted self-interviewing (audio-CASI) method, which has been shown to increase reporting of sensitive behaviors (e.g., sexual behavior, drug use, violence) and to provide better reliability and validity than face-to-face interviews or self-administered questionnaires. ${ }^{26}$

Demographic characteristics included age, ethnicity, whether either parent worked in agriculture, parents' marital status and whether they lived together, student's living situation and several social network variables-having a family member or close friend as a confidant, and if they felt pressured by friends to use methamphetamine (scored on a five-point scale from absolutely true to absolutely untrue, and dichotomized to absolutely untrue vs. all other levels). The presence of depressive symptoms was assessed by five items on the frequency of symptoms during the past three months (i.e., how often the participant felt "energetic," "down or depressed," "bored with your life," "lonely" or "optimistic about [the] future," each scored on a five-point scale from never to always; Cronbach's alpha $=0.70) ; 27$ this measure was dichotomized into low and high levels based on the number of always and almost always responses.

Participants were asked a series of questions about their use of alcohol and drugs: whether they ever went out danc- ing or drinking (i.e., went to settings where people often meet partners for casual sex), had drunk alcohol or smoked cigarettes in the past three months, had driven a motorcycle after having three or more drinks, or had ever used methamphetamine or marijuana.

For questions on sexual behavior and experience, sexual initiation was defined as the first occurrence of vaginal or anal intercourse. Students who said they had had intercourse were then asked a series of questions: their age at first intercourse; whether they had used condoms at first sex; whether they had had steady or casual partners in the past three months; their lifetime number of sexual partners; whether they had ever bought or sold sex; condom use with steady, casual and commercial partners, as well as at last intercourse (regardless of partner type); and whether they had ever been forced to have sexual contact or intercourse (and if so, at what age).

Male participants were asked about their sexual orientation. They were categorized as heterosexual if they identified themselves as such and stated that they were sexually attracted to women only. Participants expressing other combinations of sexual identity and same-sex attraction were identified as homosexual or bisexual.

Perceived risk for HIV infection was assessed by two items on the perceived risk of getting HIV and worry about getting HIV, using five-point scales from never to always (interitem r=0.58; $<$.001-not shown). Perceived risk for STIs was assessed by two similar items (interitem $\mathrm{r}=0.55$; $\mathrm{p}<.001$ ). Both scales were dichotomized based on the number of often and always responses. Answers to an 11-item HIV knowledge scale (e.g., can HIV be transmitted by: sexual intercourse, from mother to child, by sharing needles and syringes, by insect or mosquito bites, by touching people infected with the virus) and a five-item STI knowledge scale (e.g., STIs can make women infertile, STIs can be passed from mother to child) were broken into categories of low, intermediate and high, depending on the number of correct responses (i.e., agree, disagree or not sure).

\section{Statistical Analysis}

Gender differences were evaluated using the chi-square test for categorical variables and the Mann-Whitney U test for continuous variables. Survival analysis was used to compare the reported age at first sexual intercourse for male and female participants. ${ }^{28}$ Correlates of the timing of sexual initiation were evaluated separately for male and female students using Cox proportional hazards models. We expected that different models would result for males and females, because of gender differences in age at sexual initiation and gender-specific social norms for sexual behavior in Thailand. ${ }^{29}$ The variables were first entered individually to identify factors correlated with time to first intercourse in univariate analyses; rate ratios with 95\% confidence intervals were calculated for these associations. Variables that were statistically significant at $\mathrm{p}<.05$ in the univariate analyses and variables of theoretical interest were then entered into multivariate Cox survival analyses, stratified by gender. 


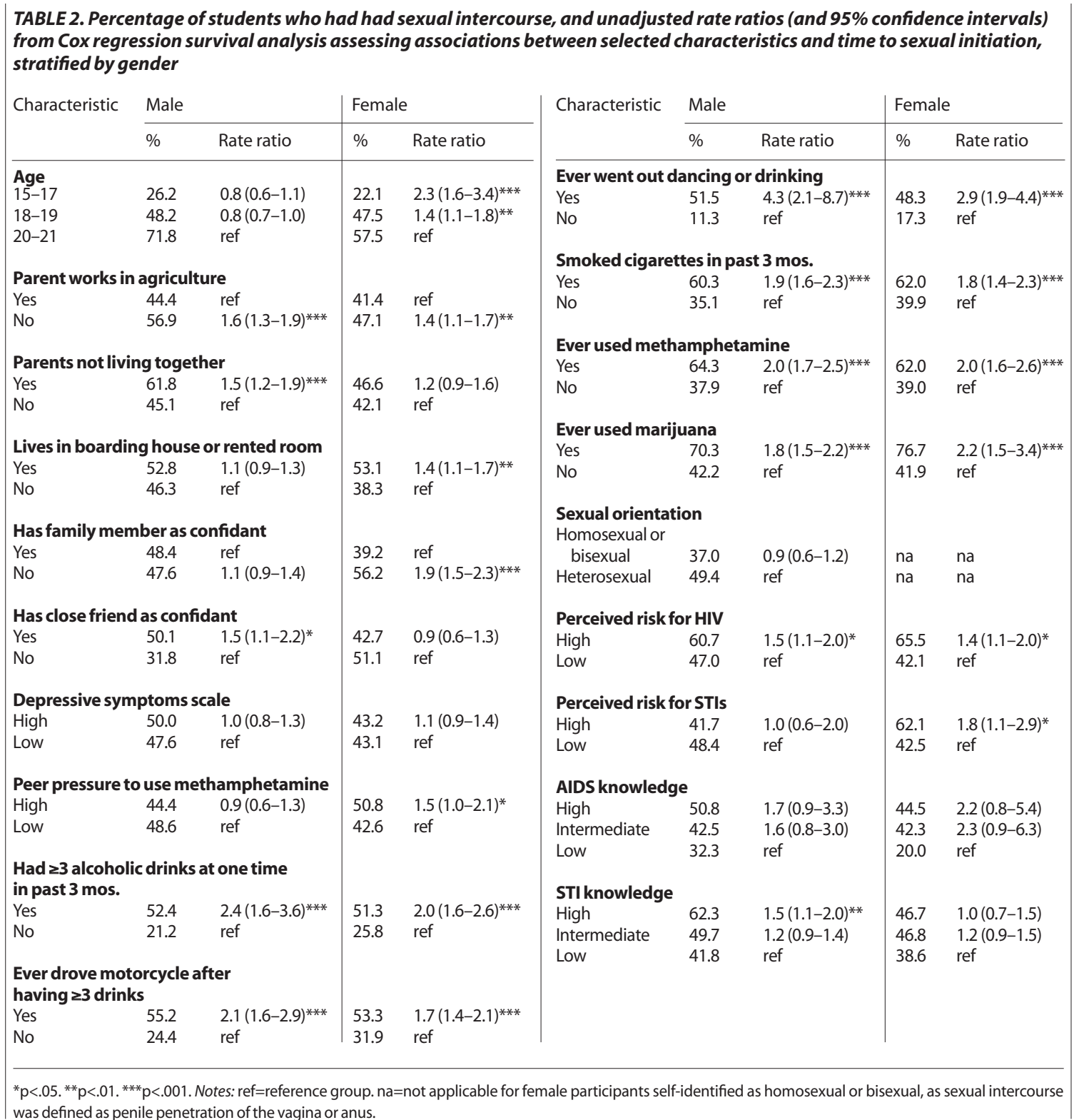

We did not identify a particular age as defining "early" sexual initiation. Instead, we used survival analysis to examine how demographic characteristics, social factors, knowledge of AIDS and STIs and perceptions of risk, and sexual and substance use behaviors were related to the age at which sexual intercourse first occurred. This permitted examination of cumulative trends in the sample by age, rather than associations with a particular age. We chose not to conduct an extreme group analysis (e.g., using very early or very late ages as reference points) or one based on median split for age because of the problems of dichotomizing dependent variables that are inherently continuous in their measurement. ${ }^{30}$ Age-specific analyses run the risk of missing cumulative factors and may be handicapped by small cell sizes for some independent variables. To achieve parsimonious models, we used backward, stepwise elimination to remove variables that did not contribute independently at $\mathrm{p}<.05$.

\section{RESULTS}

Of the 1,725 participants, the mean age was 18.4 years. Overall, $52 \%$ were male, more than nine in 10 were northern Thai and two-thirds had at least one parent who worked in agriculture (Table 1, page 127). The parents of eight in 10 participants lived together, and six in 10 students lived with their parents. Large proportions of males and females had drunk alcohol in the past three months (93\% and 81\%, respectively) and ever driven a motorcycle after having three or more drinks ( $78 \%$ vs. 53\%). Levels of substance use for males and females were significantly different, with higher proportions of males having used tobacco in the past three months ( $52 \%$ vs. $15 \%$ ) and having ever used methamphetamine (39\% vs. $18 \%$ ) or marijuana ( $22 \%$ vs. $4 \%$ ).

Some $15 \%$ of female and $18 \%$ of male students reported having had sexual contact only (defined as the respondent touching someone else's genitals, or someone else touching the respondent's genitals, for erotic stimulation, 


\section{TABLE 3. Adjusted rate ratios (and $95 \%$ confidence inter- vals) from Cox regression survival analysis assessing asso- ciations between selected characteristics of male students and time to sexual initiation}

\begin{tabular}{ll} 
Characteristic & Adjusted rate ratio \\
\hline Ever went out dancing or drinking & $2.9(1.4-5.9)^{* *}$ \\
High perceived risk for HIV & $1.7(1.3-2.3)^{* * *}$ \\
High STI knowledge & $1.7(1.2-2.2)^{* *}$ \\
Ever used methamphetamine & $1.6(1.3-2.1)^{* * *}$ \\
Has close friend as confidant & $1.6(1.1-2.4)^{*}$ \\
Neither parent works in agriculture & $1.5(1.2-1.9)^{* * *}$ \\
Smoked cigarettes in past 3 mos. & $1.5(1.2-1.9)^{* *}$ \\
Parents not living together & $1.3(1.1-1.7)^{*}$ \\
\hline
\end{tabular}

${ }^{*} p<.05 .{ }^{* *} p<.01 .{ }^{* * *} p<001$. Note: Variables were eliminated from the model in the following order: sexual orientation, has family member as confidant, age, lives in boarding house or rented room, ever used marijuana, had $\geq$ three alcoholic drinks at one time in past three months, peer pressure to use methamphetamine and STI knowledge.

including oral sex), whereas $43 \%$ of females and $48 \%$ of males had had intercourse. Among those with any sexual experience, the mean ages at first sexual contact and first intercourse were significantly earlier for males (16.0 and 16.7, respectively) than for females ( 17.2 and 17.7 , respectively). One quarter of participants had used a condom at first intercourse.

Approximately $10 \%$ of both males and females identified themselves as homosexual or bisexual. Nearly half of participants reported having a steady sexual partner in the past three months ( $42 \%$ of males and $47 \%$ of females), and smaller proportions reported having a casual partner ( $16 \%$ and $5 \%$, respectively). Males reported a higher cumulative number of sexual partners than females ( 4.6 vs. 2.8 ), and a larger proportion had ever bought sex (7\% vs. 1\%). Three percent of students had ever sold sex, and $21 \%$ of females reported ever being coerced to have sex.

On average, males initiated sexual intercourse earlier than females (rate ratio, 1.3; $<<.001-$ not shown). By age 17 for males and age 18 for females, more than one quarter reported having had intercourse (Figure 1, page 128). By age $19,56 \%$ of males and $50 \%$ of females had had intercourse.

\begin{tabular}{|c|c|}
\hline Characteristic & Adjusted rate ratio \\
\hline \multicolumn{2}{|l|}{ Age (compared with 20-21-year-olds) } \\
\hline $15-17$ & $2.4(1.6-3.5)^{* * *}$ \\
\hline $18-19$ & $1.4(1.1-1.8)^{* *}$ \\
\hline Ever went out dancing or drinking & $2.2(1.4-3.5)^{* *}$ \\
\hline High perceived risk for STls & $1.9(1.2-3.1)^{* *}$ \\
\hline Ever used marijuana & $1.6(1.0-2.6)^{*}$ \\
\hline Has no family member as confidant & $1.5(1.2-1.9)^{* *}$ \\
\hline $\begin{array}{l}\text { Had } \geq 3 \text { alcoholic drinks at } \\
\text { one time in past } 3 \text { mos. }\end{array}$ & $1.4(1.0-1.9)^{*}$ \\
\hline Ever used methamphetamine & $1.4(1.1-1.8)^{*}$ \\
\hline Neither parent works in agriculture & $1.3(1.1-1.7)^{*}$ \\
\hline Lives in boarding house or rented room & $1.3(1.0-1.6)^{*}$ \\
\hline
\end{tabular}

In the univariate analysis for males, several factors were associated with a shorter time to sexual initiation: not having a parent who worked in agriculture, having parents who did not live together, having a close friend as a confidant, a perceived high risk for HIV infection and high STI knowledge (rate ratios, 1.5-1.6-Table 2, page 129). All substance use measures were also strongly associated with earlier initiation of intercourse: having ever gone out dancing or drinking, having had three or more alcoholic drinks at one time in the past three months, having ever driven a motorcycle after consuming alcohol, having smoked cigarettes in the past three months, or having ever used methamphetamine or marijuana (1.8-4.3).

Among females, those aged 15-17 and 18-19 were more likely to have initiated sexual intercourse at an earlier age than those aged 20-21 (rate ratios, 2.3 and 1.4, respectively). Other factors associated with earlier intercourse were not having a parent who worked in agriculture, living in a boarding house or rented room, not having a family member as a confidant, high peer pressure to use methamphetamine and perceived high risk for HIV and for STIs (1.4-1.9). For females, as for males, all substance use measures showed associations with shorter time to the initiation of intercourse (1.7-2.9).

In the multivariate analysis, earlier sexual initiation for males was associated with not having a parent who worked in agriculture, having parents who did not live together, having a close friend as a confidant, a perceived high risk for HIV infection, a high level of STI knowledge, having ever gone out dancing or drinking, recent tobacco use and having ever used methamphetamine (adjusted rate ratios, 1.3-2.9-Table 3).

Independent correlates of earlier sexual initiation for females included being in the age-groups 15-17 or 18-19, not having a parent who worked in agriculture, living in a boarding house or rented room, not having a family member as a confidant, a perceived high level of risk for STI infection, having ever gone out dancing or drinking, having recently had three or more drinks at one time, and having ever used methamphetamine or marijuana (adjusted rate ratios, 1.3-2.4-Table 4).

\section{DISCUSSION}

Our findings suggest that age at sexual initiation may be influenced by a number of social factors and demographic characteristics, as well as several risk-taking behaviors, although the specific factors vary by gender. This study adds to a literature that has found that Thai females are initiating sexual intercourse at a younger age, ${ }^{31}$ a trend that coincides with premarital sex for females becoming more accepted among Thai youth. ${ }^{32}$

More than half of female participants reported having had intercourse by age 19, which suggests that their age of sexual initiation has declined over the past decade. ${ }^{33}$ In our sample, females in the 15-17 and 18-19 age-groups reported having had sexual intercourse at an earlier age than 20-21year-olds. When interpreting these data, we must consid- 
er that our use of a school-based population may select for older females who had less sexual experience, because women who became pregnant or married may have dropped out of school. Nevertheless, these results are indicative of earlier sexual initiation for women in Thailandalbeit at a later age than adolescent females in some other countries. ${ }^{34}$

Most of this shift in sexual behavior for Thai females appears attributable to the increased acceptability of premarital sex among young women. Other Thai studies have indicated that although attitudes regarding premarital relations for women have become more permissive in the past two decades, ${ }^{35}$ gender norms continue to dictate passive roles for females within intimate relationships, thereby limiting opportunities for sexual self-assertion. ${ }^{36}$ Hence, women are not expected to initiate discussions about sex, display sexual knowledge or initiate condom use. In general, expression of sexuality is more widely accepted in Thai culture for males than for females, and these norms tend to be maintained even by Thai women. ${ }^{37}$ Thai men and women also tend to view men as having much stronger sexual drives and needs than women. ${ }^{38}$

Thai men have greater freedom in their sexual lives than women, as exemplified by the society's tolerance of sexual experimentation and patronage of female sex workers by men. ${ }^{39}$ Available data suggest that age at first sex for males has changed little over the past decade. ${ }^{40}$ However, dramatic changes have occurred in males' premarital partners. Sex worker patronage among young Thai men has declined, and sex workers are no longer men's most common first sexual partners. ${ }^{41}$ Steady partnerships with girlfriends have become common, although substantial numbers of young men also have casual partners. ${ }^{42}$ The declining patronage of sex workers occurred with the rapid emergence of the HIV epidemic among Thai sex workers and their partners, ${ }^{43}$ which was accompanied by media campaigns that linked HIV infection to sex workers. ${ }^{44}$ This may have contributed to the increased frequency of noncommercial sex partners and accelerated the trend toward greater acceptability of premarital sex for young women, which had begun before the start of the HIV epidemic.

We found that social variables appeared to be associated with earlier sexual initiation, although some influences were markedly different for males and females. Coming from an agricultural background was associated with delayed sexual initiation for both genders. A previous national survey had obtained similar findings, but only for females. ${ }^{45}$ Living in a rural village in Thailand typically provides more opportunities for parents and others in the community to monitor and oversee courtship among adolescents and young adults, ${ }^{46}$ although this has diminished in recent decades. ${ }^{47}$ Rural villages may also present adolescents with fewer opportunities to engage in sexual relationships, although travel to vocational schools in urban or periurban Chiang Rai would widen these opportunities. The Thai population remains predominantly rural, yet mass media, transportation and migration to urban areas by villagers have reduced the influence of rural values, and increasing urbanization will likely continue this trend.

Other associations between family characteristics and sexual initiation were gender-specific. For males, those whose parents did not live together tended to initiate intercourse earlier than those in intact families; for females, not having a family member as a confidant and living on one's own were associated with earlier sexual initiation. Studies in other countries have found that dual-parent families, higher levels of parental monitoring and the quality of parent-adolescent communication were associated with the postponement of sexual initiation. ${ }^{48}$ One national study found that having been raised in a two-parent household was associated with later sexual initiation among Thai adolescents. ${ }^{49}$ Furthermore, parental monitoring of courtship has focused primarily on daughters, ${ }^{50}$ which would appear to be consistent with our finding that earlier sexual initiation among females was associated with not having a family member as a confidant and with living away from home; however, another study found that the quality of parentadolescent relationships was more strongly related to the likelihood of earlier sexual initiation for males than for females. ${ }^{51}$

Peer influence was a significant factor only for males, for whom the presence of a close friend as a confidant was associated with earlier sexual initiation. Although having a peer confidant does not necessarily connote "peer pressure," other research has suggested that the peer group exerts a great deal of influence over young Thai males' sexual experience and exploration. ${ }^{52}$ Research conducted elsewhere has found that those who think their peers are having sex are more likely to initiate sex themselves. ${ }^{53}$ This may also be the case in Thailand, where peer norms have been found to be associated with whether adolescents and young adults have had sexual intercourse. ${ }^{54}$

The perception of a high personal risk for HIV infection (among males) or STIs (among females) was associated with earlier sexual initiation. Moreover, young men who had had intercourse had better STI knowledge than those without such experience. The cross-sectional design of the study makes it difficult to infer how STI knowledge was temporally related to sexual experience, but research in other cultures suggests that poorer knowledge of reproductive biology is predictive of early sexual initiation. ${ }^{55}$ Hence, it would seem likely that greater knowledge of STIs may be a consequence of earlier sexual experience.

We observed no relationship between depressive symptoms and sexual initiation for either gender. On the other hand, alcohol and drug use were associated with earlier onset of sexual intercourse for males and females, as were a variety of risky behaviors assessed in this study and noted elsewhere. ${ }^{56}$ Whether experimentation with drugs predisposed individuals to engage in risky behaviors is unclear; however, such patterns have been noted in other populations. ${ }^{57}$ Sex education could be improved by including material on how substance use affects sexual risk behavior. Such efforts may be particularly valuable among these youth. 


\section{Limitations}

This study has several limitations. Its cross-sectional design does not allow us to evaluate the causality of the reported associations; a longitudinal design would be necessary to determine directionality. Also, recall bias may affect the reported age at first intercourse, although respondents may remember this kind of experience better than more mundane events. ${ }^{58}$ Underreporting of sensitive behaviors may have occurred; however, the use of audio-CASI probably maximized the level of such reporting in our study, relative to other methods. ${ }^{59}$ Another limitation is that our use of survival analysis did not fix specific bounds on what age constituted early sexual initiation, yet it did permit us to investigate the probability of sexual initiation at any age in relation to the explanatory variables, and to examine overall trends rather than those arbitrarily linked to a specific age.

Because the study was conducted in vocational schools in northern Thailand, it may not be representative of the adolescent population at large. Nonetheless, 2.5 million of the 7.5 million Thais aged 15-21 attend upper secondary and higher education, including vocational schools. ${ }^{60}$ This population tends to come from rural backgrounds, and education represents a means for upward economic mobility and preparation for the urban workforce. Hence our sample may provide some insight into a large and important segment of Thai society that is seeking economic advancement and that may be particularly affected by the social changes occurring in Thailand.

\section{Implications}

Addressing sexual risk behavior in Thailand is a challenge because open discussion of sex-related topics is considered a societal taboo, particularly for young women, although some interventions have been able to address communication in mixed-gender groups. ${ }^{61}$ Effective sex education may be difficult to achieve in Thailand: Sex education as a formal subject is currently limited in Thai school curricula, ${ }^{62}$ and instructors are often reluctant to teach it in the classroom. Similar problems have been noted in other service professions that have significant contact with adolescents and young adults. ${ }^{63}$ There is a critical need to inform young Thais about the possible adverse consequences of sexual activity-such as unplanned or unwanted pregnancy, STIs and HIV-and about ways to protect themselves against these risks. Although early sexual initiation in our sample was associated with social variables, most of the related factors appear to be amenable to intervention.

More attention needs to be directed to social influences such as parents and peer groups. Our findings indicate that parents play an influential role as monitors of their daughters' sexual behavior, ${ }^{64}$ and efforts to improve parentadolescent communication about sexuality issues may be particularly effective. Peers appear to influence the sexual behavior of young Thai men, ${ }^{65}$ and interventions directed at peer norms may be especially helpful to them. These kinds of interventions have had significant effects on the sexual attitudes and intentions of Thai youth. ${ }^{66}$
In general, sex education needs to consider sexual behavior in the context of substance abuse and generalized risk-taking, and also take into account that some early sexual experience may be coerced or unwanted. Different messages targeted at sexually inexperienced and sexually experienced youth are more likely to influence them to reduce their risk-taking behavior. Youth who have not initiated sex may not recognize that acquiring HIV or STIs is a potential consequence of sexual initiation, and experienced youth may be unaware of the additional risks to which they are exposed because of their behavior. Targeted interventions may better prepare Thai youth to ably negotiate the sexual and health challenges of their adolescent years.

\section{REFERENCES}

1. Sittitrai W et al., Thai Sexual Behavior and Risk of HIV Infection: A Report of the 1990 Survey of Partner Relations and Risk of HIV Infection in Thailand, Bangkok: Thai Red Cross Society, 1992.

2. Xenos P, Pitaktepsombati P and Sittitrai W, Partner patterns in the sexual behavior of unmarried, rural Thai men, Asia Pacific Population Forum, 1993, 6(4):104-117; Cash K, Women educating women for HIV/AIDS prevention, in: Long LD and Ankrah EM, eds., Women's Experiences with HIV/AIDS: An International Perspective, New York: Columbia University Press, 1996, pp. 311-332; Mills S et al., HIV risk behavioral surveillance in Bangkok, Thailand: sexual behavior trends among eight population groups, AIDS, 1997, 11(Suppl. 1):S43-S51; Podhisita C and Pattaravanich U, Youth in Contemporary Thailand: Results from the Family and Youth Survey, Nakhon Pathom, Thailand: Institute for Population and Social Research, Mahidol University, 1995, Publication No. 197; and Soonthornhada A, Adolescent role behavior, expectations and adaptations: past to present, in: Yoddumnern-Attig B et al., Changing Roles and Statuses of Women in Thailand: A Documentary Assessment, Nakhon Pathom, Thailand: Institute for Population and Social Research, Mahidol University, 1992, Publication No. 161, pp. 55-63.

3. Cash K, 1996, op. cit. (see reference 2); Podhisita C and Pattaravanich U, 1995, op. cit. (see reference 2); and van Griensven F et al., Rapid assessment of sexual behavior, drug use, human immunodeficiency virus, and sexually transmitted diseases in northern Thai youth using audiocomputer-assisted self-interviewing and noninvasive specimen collection, Pediatrics, 2001, 108(1):e13, <http://pediatrics.org/cgi/content/ full/108/1/e13>, accessed Aug. 6, 2006.

4. van Griensven F et al., 2001, op. cit. (see reference 3); Jenkins RA et al., Dynamics of HIV risk behavior among young Thai men, AIDS and Behavior, 1999, 3(4):335-346; Kilmarx PH et al., Explosive spread and effective control of human immunodeficiency virus in northernmost Thailand: the epidemic in Chiang Rai province, 1988-99, AIDS, 2000, 14(17):2731-2740; Kitsiripornchai S et al., Sexual behavior of young men in Thailand: regional differences and evidence of behavior change, Journal of Acquired Immune Deficiency Syndromes and Human Retrovirology, 1998, 18(3):282-288; and Nelson KE et al., HIV infection in young men in northern Thailand, 1991-1998: increasing role of injection drug use, JAIDS: Journal of Acquired Immune Deficiency Syndromes, 2002, 29(1):62-68.

5. Ibid.

6. Albrecht H, HIV incidence trends in young women, AIDS Clinical Care, 2001, 13(10):94-99; Buga GA, Amoko DH and Ncayiyana DJ, Sexual behavior, contraceptive practice, and reproductive health among school adolescents in rural Transkei, East African Medical Journal, 1996, 73(2):95-100; Centers for Disease Control and Prevention, National and state-specific pregnancy rates among adolescents-United States, 1995-1997, Morbidity and Mortality Weekly Report, 2000, 49(27):605611; Nicoll A et al., Sexual health of teenagers in England and Wales: analysis of national data, British Medical Journal, 1999, 318(7194): 1321-1322; and Orr DP et al., Subsequent sexually transmitted infection in urban adolescents and young adults, Archives of Pediatrics $\varepsilon$ Adolescent Medicine, 2001, 155(8):947-953.

7. Podhisita C, Xenos P and Varangrat A, The risk of premarital sex 
among Thai youth: individual and family influence, Journal of Population and Social Studies, 2004, 12(2):1-31; and Choe MK et al., Substance use and premarital sex among adolescents in Indonesia, Nepal, the Philippines, and Thailand, Asia-Pacific Population Journal, 2004, 19(1):5-26.

8. Ford N and Kittisuksathit S, Destinations unknown: the gender construction and changing nature of the sexual expression of Thai youth, AIDS Care, 1994, 6(5):517-531; and Ford NJ and Kittisuksathit S, Youth Sexuality: The Sexual Awareness, Lifestyles and Related Health Service Needs of Young, Single Factory Workers in Thailand, Nakhon Pathom, Thailand: Institute for Population and Social Research, Mahidol University, 1996, Research Report No. 204.

9. Podhisita C, Xenos P and Varangrat A, 2004, op. cit. (see reference 7).

10. Podhisita C and Pattaravanich U, 1995, op. cit. (see reference 2); Podhisita C, Xenos P and Varangrat A, 2004, op. cit. (see reference 7); and Choe MK et al., 2004, op. cit. (see reference 7).

11. Podhisita C, Xenos P and Varangrat A, 2004, op. cit. (see reference 7).

12. Ibid.

13. Choe MK et al., 2004, op. cit. (see reference 7).

14. Ibid.; and Podhisita C, Xenos P and Varangrat A, 2004, op. cit. (see reference 7).

15. Podhisita C, Xenos P and Varangrat A, 2004, op. cit. (see reference 7).

16. Buga GA, Amoko DH and Ncayiyana DJ, 1996, op. cit. (see reference 6); Meschke LL and Silbereisen RK, The influences of puberty, family processes, and leisure activities on the timing of the first sexual experience, Journal of Adolescence, 1997, 20(4):403-418; Kraft P, Age at first experience of intercourse among Norwegian adolescents: a lifestyle perspective, Social Science \& Medicine, 1991, 33(2):207-213; and Kinsman $S$ et al., Early sexual initiation: the role of peer norms, Pediatrics, 1998, 102(5):1185-1192.

17. Royal Thai National Statistical Office, National Statistical Yearbook, Thailand 1998, Bangkok: Royal Thai National Statistical Office, 1998.

18. Kilmarx PH et al., 2000, op. cit. (see reference 4); and Weniger BG et al., The epidemiology of HIV infection and AIDS in Thailand, AIDS, 1991, 5(Suppl. 2):S71-S85.

19. Kilmarx PH et al., 2000, op. cit. (see reference 4); van Griensven F et al., The Use of Mortality Statistics as a Proxy Indicator for the Impact of the AIDS Epidemic on the Thai Population, Bangkok: Institute of Population Studies, Chulalongkorn University, 1998, Publication No. 267/98.

20. Mills S et al., 1997, op. cit. (see reference 2).

21. Royal Thai Ministry of Education, Educational Management Information System Centre, Bangkok: Royal Thai Ministry of Education, 1997.

22. Manopaiboon C, Sexual coercion among adolescents in northern Thailand: prevalence and risk factors, Southeast Asian Journal of Tropical Medicine and Public Health, 2003, 34(2):447-457.

23. van Griensven F, The prevalence of homosexual and bisexual orientation and related health risks among adolescents in northern Thailand, Archives of Sexual Behavior, 2004, 33(2):137-147.

24. Sandhikshetrin K, ed., Civil and Commercial Code of Thailand, Books I-VI and Glossary, Bangkok: Nititham Publishing House, 1996.

25. van Griensven F et al., 2001, op. cit. (see reference 3).

26. Des Jarlais DC et al., Audio-computer interviewing to measure risk behavior for HIV among injecting drug users: a quasi randomized trial, Lancet, 1999, 353(9165):1657-1661; Turner CF et al., Adolescent sexual behavior, drug use, and violence: increased reporting with computer survey technology, Science, 1998, 28(5365):867-873; and van Griensven F et al., Palmtop-assisted self-interviewing for the collection of sensitive behavioral data: randomized trial with drug use urine testing, American Journal of Epidemiology, 2006, 163(2):271-278.

27. Cronbach L, Coefficient alpha and the internal structure of tests, Psychometrika, 1951, 16(3):297-334.
28. Cox DR and Oakes D, Analysis of Survival Data, New York: Chapman and Hall, 1984.

29. Sittitrai W et al., 1992, op. cit. (see reference 1); Xenos P, Pitaktepsombati P and Sittitrai W, 1993, op. cit. (see reference 2); Podhisita C and Pattaravanich U, 1995, op. cit. (see reference 2); Soonthornhada A, 1992, op. cit. (see reference 2); Ford N and Kittisuksathit S, 1994, op. cit. (see reference 8); Ford NJ and Kittisuksathit S, 1996, op. cit. (see reference 8); Im-Em W, Changing partner relations in the era of AIDS in upper-north Thailand, in: Caldwell JC et al., eds., Resistances to Behavioral Change to Reduce HIV/AIDS Infection, Canberra, Australia: Health Transition Centre, National Centre for Epidemiology and Population Health, Australian National University, 1999, pp. 157-170; Havanon N, Talking to men and women about their sexual relationships: insights from a Thai study, in: Zeidenstein $S$ and Moore K, eds., Learning About Sexuality: A Practical Beginning, New York: International Women's Health Coalition and Population Council, 1996, pp. 110-118; and Knodel J et al., Thai views of sexuality and sexual behaviour, Health Transition Review, 1996, 6(2):179-201.

30. MacCallum RC et al., On the practice of dichotomization of quantitative variables, Psychological Methods, 2002, 7(1):19-40; and Preacher $\mathrm{KJ}$ et al., Use of the extreme groups approach: a critical reexamination and new recommendations, Psychological Methods, 2005, 10(2):178-192.

31. Podhisita C and Pattaravanich U, 1995, op. cit. (see reference 2).

32. Cash K, 1996, op. cit. (see reference 2); Podhisita C and Pattaravanich U, 1995, op. cit. (see reference 2); and Havanon N, 1996, op. cit. (see reference 29).

33. Sittitrai W et al., 1992, op. cit. (see reference 1); Xenos P, Pitaktepsombati P and Sittitrai W, 1993, op. cit. (see reference 2); Cash K, 1996, op. cit. (see reference 2); Podhisita C and Pattaravanich U, 1995, op. cit. (see reference 2); and Soonthornhada A, 1992, op. cit. (see reference 2).

34. Orr DP et al., 2001, op. cit. (see reference 6); Manzini N, Sexual initiation and childbearing among adolescent girls in KwaZulu Natal, South Africa, Reproductive Health Matters, 2001, 9(17):44-52; and Singh S and Darroch JE, Trends in sexual activity among adolescent American women: 1982-1995, Family Planning Perspectives, 1999, 31(5):212-219.

35. Podhisita C and Pattaravanich U, 1995, op. cit. (see reference 2); and Im-Em W, 1999, op. cit. (see reference 29).

36. Knodel J et al., 1996, op. cit. (see reference 29).

37. Xenos P, Pitaktepsombati P and Sittitrai W, 1993, op. cit. (see reference 2); Ford N and Kittisuksathit S, 1994, op. cit. (see reference 8); Ford NJ and Kittisuksathit S, 1996, op. cit. (see reference 8); Im-Em W, 1999, op. cit. (see reference 29); Havanon N, 1996, op. cit. (see reference 29); and Knodel J et al., 1996, op. cit. (see reference 29).

38. Ford N and Kittisuksathit S, 1994, op. cit. (see reference 8); Ford NJ and Kittisuksathit S, 1996, op. cit. (see reference 8); Im-Em W, 1999, op. cit. (see reference 29); Havanon N, 1996, op. cit. (see reference 29); Knodel J et al., 1996, op. cit. (see reference 29); and Taywaditep K, Thailand (Maunag Thai), in: Francoeur R, ed., The Continuum Complete International Encyclopaedia of Sexuality, New York: Continuum Publishing, 2004, pp. 1021-1053.

39. Ford N and Kittisuksathit S, 1994, op. cit. (see reference 8).

40. Sittitrai W et al., 1992, op. cit. (see reference 1); Xenos P, Pitaktepsombati P and Sittitrai W, 1993, op. cit. (see reference 2); van Griensven F et al., 2001, op. cit. (see reference 3); Jenkins RA et al., 1999, op. cit. (see reference 4); Kitsiripornchai S et al., 1998, op. cit. (see reference 4); and Nelson KE et al., 2002, op. cit. (see reference 4).

41. Ibid.

42. Jenkins RA et al., 1999, op. cit. (see reference 4); and Nelson KE et al., 2002, op. cit. (see reference 4).

43. Nelson KE et al., 2002, op. cit. (see reference 4).

44. Lyttleton C, Endangered Relations: Negotiating Sex and AIDS in Thailand, New York: Harwood, 2000.

45. Podhisita C and Pattaravanich U, 1995, op. cit. (see reference 2); Choe MK et al., 2004, op. cit. (see reference 7); and Podhisita C, Xenos PFnd Varangrat A, 2004, op. cit. (see reference 7). 
46. Ford N and Kittisuksathit S, 1994, op. cit. (see reference 8); and Ford NJ and Kittisuksathit S, 1996, op. cit. (see reference 8). 47. Klausner WJ, Thai Culture in Transition, Bangkok: Siam Society, 1997.

48. Meschke LL and Silbereisen RK, 1997, op. cit. (see reference 16); Lammers C et al., Influences on adolescents' decision to postpone onset of sexual intercourse: a survival analysis of virginity among youths aged 13 to 18 years, Journal of Adolescent Health, 2000, 26(1):42-48; Rosenthal SL et al., Sexual initiation: predictors and developmental trends, Sexually Transmitted Diseases, 2001, 28(9):527-532; Karofsky PS et al., Relationship between adolescent-parental communication and initiation of first intercourse by adolescents, Journal of Adolescent Health, 2001, 28(1):41-45; Resnick MD et al., Protecting adolescents from harm: findings from the National Longitudinal Study on Adolescent Health, Journal of the American Medical Association, 1997, 278(10):823-832; and Sieving RE et al., Maternal expectations, mother-child connectedness, and adolescent sexual debut, Archives of Pediatrics \& Adolescent Medicine, 2000, 154(8):809-816.

49. Choe MK et al., 2004, op. cit. (see reference 7); and Podhisita C, Xenos P and Varangrat A, 2004, op. cit. (see reference 7).

50. Ford N and Kittisuksathit S, 1994, op. cit. (see reference 8); Ford NJ and Kittisuksathit S, 1996, op. cit. (see reference 8); and Klausner WJ, 1997, op. cit. (see reference 47).

51. Podhisita C, Xenos P and Varangrat A, 2004, op. cit. (see reference 7).

52. VanLandingham M et al., In the company of friends: peer influence on Thai male extramarital sex, Social Science \& Medicine, 1998, 47(12):1993-2011

53. Kinsman S et al., 1998, op. cit. (see reference 16).

54. Podhisita C, Xenos P and Varangrat A, 2004, op. cit. (see reference 7).

55. Buga GA, Amoko DH and Ncayiyana DJ, 1996, op. cit. (see reference 6); and Fergusson DM and Lynskey MT, Alcohol misuse and adolescent sexual behaviors and risk taking, Pediatrics, 1996, 98(1):91-96.

56. Allen DR et al., Sexual health risks among young Thai women: implications for HIV/STD prevention and contraception, AIDS and Behavior 2003, 7(1):9-21; Jenkins RA et al., Determinants of condom use and intentions to use condoms among northern Thai youth, AIDS Education and Prevention, 2002, 14(2):228-245; and Pitaktong U et al., Helmet use and related risk behaviors among young motorcyclists in northern Thailand, 2004, Southeast Asian Journal of Tropical Medicine and Public Health, 35(2):232-241

57. Resnick MD et al., 1997, op. cit. (see reference 48); Fergusson DM and Lynskey MT, 1996, op. cit. (see reference 55); and Halpern-Felsher BL et al., Relationship of alcohol use and risky sexual behavior: a review and analysis of findings, Journal of Adolescent Health, 1996, 19(5):331-336.

58. Touraneau R et al., The Psychology of Survey Response, New York: Cambridge University Press, 2000.

59. Des Jarlais DC et al., 1999, op. cit. (see reference 26); and Turner CF et al., 1998, op. cit. (see reference 26).

60. Royal Thai Ministry of Education, 1997, op. cit. (see reference 21).

61. Cash K et al., AIDS Prevention Through Peer Education for Northern Thai Single Migratory Factory Workers, Washington, DC: International Center for Research on Women, 1997.

62. Gray A and Punpuing S, Gender, Sexuality and Reproductive Health in Thailand, Nakhon Pathom, Thailand: Institute for Population and Social Research, Mahidol University, 1999, Research Report No. 232.

63. Beyrer C, War in the Blood: Sex, Politics and AIDS in Southeast Asia, London and New York: Zed Books, 1998.

64. Ford N and Kittisuksathit S, 1994, op. cit. (see reference 8); and Ford NJ and Kittisuksathit S, 1996, op. cit. (see reference 8).

65. VanLandingham M et al., 1998, op. cit. (see reference 52).

66. Cash K, 1996, op. cit. (see reference 2); and Cash K et al., 1997, op. cit. (see reference 61).

\section{RESUMEN}

Contexto: Durante las últimas dos décadas, cambios sociales dramáticos han ocurrido en Tailandia; no obstante, hay pocos conocimientos sobre los factores relacionados con la iniciación sexual de los adolescentes.

Métodos: Se llevó a cabo una encuesta mediante audio-entrevistas asistidas por computadora para evaluar las características sociales y demográficas, el uso de sustancias, la conducta sexual, y los conocimientos acerca de la infección del VIH y las ITS. Se entrevistaron a 1.725 estudiantes de escuelas vocacionales, de 15-21 años de edad, residentes en la región norte de Tailandia. Las diferencias entre los géneros con respecto a estos factores se evaluaron mediante pruebas de chi cuadrada y pruebas U de Mann-Whitney. Se evaluaron las relaciones entre estas variables y la iniciación sexual de cada género a través del análisis multivariado de supervivencia utilizando modelos de Cox de riesgo proporcional.

Resultados: Los varones iniciaron sus relaciones sexuales a una edad más temprana que las mujeres; la edad mediana de la primera relación fue de 17 y 18 años, respectivamente. La iniciación sexual estuvo relacionada con haber pertenecido a un entorno no agrícola y al uso de alcohol o metanfetamina (razones de riesgo ajustadas, 1,3-2,9). En el caso de los hombres, la iniciación sexual también estuvo relacionada con otros factores, incluidos la separación de sus padres, tener un amigo confidente, consumo de tabaco, tener un riesgo percibido elevado de la infección por VIH, y tener un nivel alto de conocimiento de las ITS $(1,3-1,7)$. Con respecto a las mujeres, los factores relacionados con la iniciación sexual a temprana edad eran la menor edad, vivir fuera del núcleo familiar, no poder compartir sus confidencias con un miembro de su familia, riesgo percibido elevado de las ITS y haber fumado marihuana alguna vez (1,3-2,4).

Conclusiones: Las intervenciones dirigidas a mejorar las consecuencias adversas de la iniciación sexual a temprana edad deben abordar las influencias sociales tales como las relaciones con los padres y con los pares. Los programas deben identificar y concentrar la atención en los subgrupos de alto riesgo, tales como aquellos que a temprana edad ya tienen experiencia sexual y los que presentan conductas proclives a tomar riesgos.

\section{RÉSUMÉ}

Contexte: La Thaïlande a enregistré une profonde transformation sociale ces 20 dernières années. Les facteurs d'initiation sexuelle des adolescents demeurent toutefois peu connus. Méthodes: Une enquête basée sur la méthode d'auto-entrevue audio assistée par ordinateur a été menée pour évaluer les caractéristiques sociales et démographiques, l'usage de substances intoxicantes, le comportement sexuel et la sensibilisation aux VIH et IST parmi 1.725 élèves de l'enseignement professionnels âgés de 15 à 21 ans dans le nord de la Thaïlande. Les différences entre les sexes ont été évaluées, pour ces facteurs, par tests chi carré et Mann-Whitney U. L'analyse de survie multivariée, par modèles de risques proportionnels de Cox, a permis d'évaluer les associations entre ces variables et l'initiation sexuelle de chaque sexe.

Résultats: Les garçons connaissent leurs premiers rapports se- 
xuels à un âge plus jeune que les filles, l'âge médian au moment des premiers rapports étant, respectivement, de 17 et 18 ans. L'initiation sexuelle s'est révélée associée à des antécédents non agricoles et à la consommation d'alcool ou de méthamphétamine (rapports de taux ajustés, 1,3-2,9). Pour les garçons, l'initiation était aussi associée au fait d'avoir des parents ne vivant pas ensemble, à celui d'avoir un ami comme confident, à l'usage du tabac, à un haut risque perçu de VIH et à une haute sensibilisation aux IST (1,3-1,7). Côté féminin, d'autres facteurs associés à l'initiation se sont avérés le jeune âge, la vie séparée de la famille, l'absence d'un parent comme confident, le hau trisque perçu d'IST et le fait d'avoir jamais fumé de la marijuana (1,3-2,4). Conclusions: Les interventions visant à améliorer les conséquences adverses de l'initiation sexuelle précoce doivent considérer les influences sociales telles que les parents et les groupes de pairs. Les programmes doivent identifier et cibler les sousgroupes à risques élevés: les jeunes sexuellement expérimentés à un âge précoce et ceux engagés dans des modèles de prise de risque généralisée.

\section{Acknowledgments}

The authors thank the directors, staff and students of the schools in Chiang Rai for their participation in the study. They also thank Khanchit Limpakarnjanarat, Timothy Mastro, Jordan Tappero, Supaporn Chaikummao and the staff of the Thailand Ministry of Public Health-U.S. CDC Collaboration in Nonthaburi and Chiang Rai for their support and dedication. The authors appreciate Linda Koenig's helpful comments on an earlier version of this article.

Author contact: jenkinsri@mail.nih.gov 